\title{
Comparative Epidemiological Studies on Gallbladder Cancer between Chile and Japan
}

\author{
Masaharu Yamamoto ${ }^{1}$, I. Serra ${ }^{2}$, I. Roa, A. Calvo ${ }^{4}$, H. Watanabe ${ }^{5}$ \\ K. ENDOH $^{1}$, N. ShibUYA ${ }^{1}$ and K. NaKamura ${ }^{1}$
}

\section{RESUMEN}

Se ha realizado un estudio del cáncer vesicular entre 1991 y 1998 en Chile. Presentamos los principales hallazgos encontrados en esta investigación y se comparan con los datos equivalentes de Japón.

1) Hemos examinado el índice de mortalidad del cáncer vesicular en 39 países del mundo. Chile y Japón tienen dos de las más altas tasas de mortalidad por cáncer biliar, expresado en el cáncer de vesícula biliar y la vía extrahepática.

2) La actividad mutagénica de la bilis fue comparada entre las mujeres chilenas y japonesas con cálculos de vesícula por el test de Ames (Ta 98+S9 mix y TA 100+S9 mix) con absorción de blue rayon. Los rangos mutagénicos observados entre las muestras de bilis chilenas y japonesas fueron casi idénticas $(83,3 \%$ vs $80,8 \%$ ), pero la bilis de pacientes chilenas mostró una alta actividad mutagénica en términos del número de colonias revertidas (128 vs 62 )

3) El estudio control de cáncer de vesícula biliar fue realizado con 74 mujeres chilenas portadoras de cálculos biliares, en el sentido de si los cálculos eran un factor definitivo de riesgo para el cáncer de vías biliares. En estos estudios se encontró que existen otros factores de riesgo de cáncer, que pudieran contribuir asociadamente, como el consumo habitual de ají que conlleva un significativo mayor riesgo en Chile, pero no ha sido consignado como factor de riesgo en Japón. Ahora es necesario, buscar la identificación de substancias químicas presentes en el ají que pueden contribuir a la ocurrencia de cáncer de vesícula.

1 Department of Hygiene and Preventive Medicine, Niigata University School of Medicine.

2 School of Public Health, University of Chile.

3 Department of Pathology, La Frontera University.

4 Department of Surgery, Sotero del Rio Hospital.

5 The First Department of Pathology, Niigata University School of Medicine.
4) El rango de alteraciones p53 presentes en el cáncer de vesícula es casi idéntica en Chile y Japón $(55,0 \%$ vs $50,0 \%)$ pero el aspecto-base difiere grandemente, siguiendo una diferencia regional en las causas carcinogénicas.

\section{Introduction}

In 1991, I (Yamamoto) became a member of the International Scientific Research Program sponsored by the Ministry of Education of Japan, and was given the opportunity to extend our research work (Endoh et al., 1993; Yamamoto et al., 1993) on gallbladder cancer GBC) to a global level. In seeking to accomplish our research aims, I was most fortunate in finding true friends in Santiago, Chile, where Dr. Iván Sena, Dr. Alfonso Calvo and I have now been conducting an international collaborative study on the epidemiology of GBC for about 8 years.

I have made another true friend in Temuco, Chile: Dr. Iván Roa, Professor of Pathology at La Frontera University. Since 1991, we have been engaged in epidemiological studies on gallbladder cancer in Chile and have been able to report various scientific data in this field.

The aim of this paper is not only to report the findings obtained in Chile, but also to compare them with Japanese data. Since most of our work has already been published elsewhere, we provide here a summary with special attention to data obtained recently.

Our study object in the broad sense is biliary tract cancer (BTC), which consists of gallbladder cancer (GBC) and extrahepatic bile duct cancer (BDC). In an early stage of our studies, we analyzed demographic data for BTC using death certificates, since we were confident of their reliability. With recent improvements in diagnostic accuracy, it has become possible to analyze the mortality rates of GBC and BDC separately. Strict criteria were applied for the medical terminology used in this paper. 


\section{Materials and Methods}

\section{Mortality Analysis of BTC World-Wide}

Mortality data on BTC in 39 countries (1981-1986) was obtained from WHO. Recent world population data was gathered from the Demographic Yearbook. The indirect method was adopted for the calculation of standardized mortality ratios (SMRs). The male and female specific standard populations and standard death numbers were calculated by summing up age and sex-specific populations and death numbers in 39 countries. Details of the methods were described in Chen et al. (1990).

\section{Mutagenic Activity of Bile from Chilean and Japanese Patients with Cholelithiasis}

Bile samples were obtained from female patients with GS, all of whom had undergone cholecystectomy surgery. Bile was collected from the resected gallbladders and stored at $-20^{\circ} \mathrm{C}$ until blue rayon treatment. Chilean bile samples were collected in Temuco. Japanese samples were from Niigata and Kochi prefectures, which are high and low-risk areas for GBC, respectively (Kodama et al., 1998). Mutagenicity was confirmed by the preincubation method using Salmonella typhimurium TA98 in the presence of S9 mix. Details of the materials and methods were reported by Mano et al. (1996).

\section{Case-Control Study of GBC in Chile}

A case-control study of GBC was conducted on 90 cases registered at Sotero del Rio Hospital in Santiago from 1992 to 1994. Controls were selected from among outpatients of the same hospital who received abdominal echography. Each case was assigned two age and sex-matched controls, either with or without GS. A questionnaire was used to obtain information concerning risk factors for GBC. Details of the subjects and methods were reported by Serra et al. (1996).

Seventy-four female pairs were selected for the present analysis using a conditional multiple logistic model. Details of the method were described by Endoh et al. (1997).

\section{Mutagenic Analysis of Chili Pepper}

Red chili pepper samples were purchased at a market in Santiago, Chile. Twenty grams of ground dry chili without seeds were added to $400 \mathrm{ml}$ of methanol solution. The mixture was stirred and sonicated for 10 minutes at room temperature. The eluates were filtered and evaporated to dryness. Residues were then distributed between water and hexane $(1: 6, \mathrm{v} / \mathrm{v})$ by shaking the mixture for 30 minutes, and water and hexane layers were obtained.

Fractionation of the water layer was performed by column chromatography. Sixty $\mathrm{ml}$ of water layer were injected into a column of Sep-Pak C18 $(5 \mathrm{~g} /$ $20 \mathrm{cc}$, Waters) and then another $30 \mathrm{ml}$ of water were added. The column was eluted by a mobile phase of methanol/water, and 10 fractions were obtained, as shown in Fig. 1.

The water and hexane layers, and 10 water fractions, were evaporated to dryness and dissolved with DMSO. The mutagenic activity of these 12 samples was tested using Salmonella typhimurium strain TA98 in the presence of S9 mix, as detailed earlier by Mano et al. (1996).

\section{5.p53 Analysis of GBC}

GBC specimens were obtained from patients in two high-prevalence areas, Niigata, Japan, and Santiago, Chile. These were analyzed for acquired mutations in exons 5-8 of the p53 tumor suppressor gene, and the findings for the two groups were compared. Details of the materials and methods were described in Yokoyama et al. (1998).

\section{Results and Discussion}

\section{Mortality Analysis of BTC World-Wide}

Among 39 countries, Chile ranked first in both sexes. Japan ranked 2nd for males and 5 th for females. Thus Chile and Japan were established to have two of the highest mortality rates for BTC in the world. More precise results are reported in Chen et al. (1990).

\section{Mutagenic Activity of Bile from Chilean and Japanese Patients with Cholelithiasis}

Of 24 bile samples collected in Chile, 20 (83.3\%) showed mutagenicity. Of the Japanese bile samples, $21(80.8 \%)$ of 26 from Niigata and $5(19.2 \%)$ of 26 from Kochi were mutagenic. Therefore, both the Chilean and the Japanese samples collected in high risk areas showed higher mutagenic rates than the Japanese ones from a low-risk area. The proportion 
of Chilean positive samples increased with age. With Japanese bile samples from both high- and low- risk areas, there was a tendency toward higher mutagenicity rates in older age groups.

The average numbers of revertant colonies with samples from Temuco, Niigata and Kochi, were 128, 62, and 66, respectively. Thus, Chilean bile tended to show higher mutagenic activity than Japanese (Mano et al., 1996).

\section{Case-Control Study of GBC in Chile}

This is the most important of these collaborative studies between Chile and Japan. As the senior author of this study, Sena et al. (1996) published preliminary results and suggested that chili pepper consumption might be a risk factor for GBC.

The case-control study was based on our working hypothesis that multiple factors cause GBC. Since it has been established that GSs are one definite risk factor, we tried to discover others which might work in association.

From their univariate analysis of 90 cases, Serra et al. (1996) found that the odds ratios were significantly higher for chili pepper consumption in the subject cases than the controls. Endoh et al. (1997) selected 74 female cases from the original 90 and analyzed them using a conditional logistic model. The results confirmed Dr. Serra's findings (1996). Here we present only the essence of the results obtained.

As shown in Table 1 presence of a dose-response relationship with green chili consumption could be established, with odds ratios higher at increased frequency levels. The data for red chili peppers (Table 2) demonstrated an even greater dosedependent increase. Based on these epidemiological findings, identification of the included mutagenic/ carcinogenic substance(s) which is related to the occurrence of GBC is a high priority.

\begin{tabular}{lccccc}
\hline & \multicolumn{4}{c}{ Consumption of green chili } \\
\cline { 2 - 5 } Frequency levels & Cases & Controls & Total & Odds ratio & $95 \%$ CI. \\
\hline (0) Rarely & 29 & 97 & 126 & 1.00 & \\
(1) $1-2$ times/week & 11 & 17 & 28 & 2.16 & $0.81-5.79$ \\
(2) $3-7$ times/week & 20 & 22 & 42 & 3.04 & $1.41-6.55$ \\
(3) $\geq 8$ times/week & 14 & 12 & 26 & 3.90 & $1.57-9.68$ \\
\hline Total & 74 & 148 & $222 \quad x^{2}=15.184(\mathrm{P}=0.0001)$ & \\
\hline
\end{tabular}

Note: Tested by the Mantel-extension method

Table 1. Odds ratio by the frequency of green chili consumption.

\begin{tabular}{lccccc}
\hline & \multicolumn{5}{c}{ Consumption of red chili } \\
\cline { 2 - 6 } Frequency le veis & Cases & Controls & Total & Odds ratio & $95 \%$ CI. \\
\hline (0) Rarely & 28 & 102 & 130 & 1.00 & 3.12 \\
(1) $1-2$ times/week & 18 & 21 & 39 & 3.43 & $1.42-6.88$ \\
(2) $3-7$ times/week & 16 & 17 & 33 & 5.90 & $2.02-14.76$ \\
(3) $\geq 8$ times/week & 12 & 8 & 20 & $\mathrm{x}^{2}=20.359(\mathrm{P}<0.0001)$ \\
\hline Total & 74 & 148 & 222 & \\
\hline
\end{tabular}

Note: Tested by the Mantel-extension method

Table 2. Odds ratio by the frequency of red chili consumption. 


\section{Mutagenic Analysis of Chili Pepper}

We obtained hexane and water extracts from red chili pepper without seeds, and each of the extracts was tested for mutagenicity using the Ames assay with Salmonella typhimurium strains TA98 and TA 100 with S9 mix. We found that the water layer showed mutagenicity in this system, but the hexane layer did not.

Next, we made an attempt to isolate fractions by using a Sep-Pak C18 column and obtained 10 fractions Fl to F10 (Fig. 1). Of the 10 fractions tested, only the FS fraction showed mutagenicity.
As shown in Fig. 2, a dose-response relationship was observed.

In addition to the analysis of fractions, we investigated the destination of capsaicin in the 10 fractions, since capsaicin is a major ingredient of capsicum fruits. We found that capsaicin did not drop into fraction FS, but into F6. Additional investigation revealed that capsaicin (synthesized) did not show any mutagenicity at all in this assay system (Fig. 3). We must therefore continue our efforts to discover the unknown chemical substance(s) existing either in chili peppers themselves or in some contaminant, such as fungi.

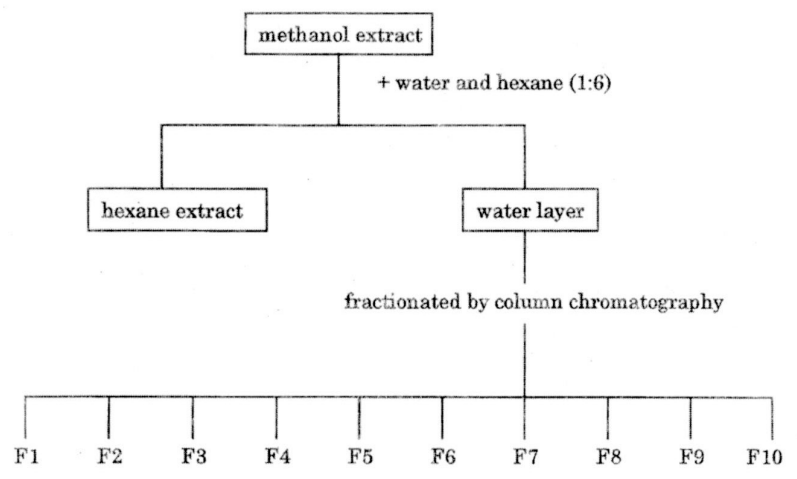

Fig. 1. Procedures for extraction and franctionation of chili pepper.

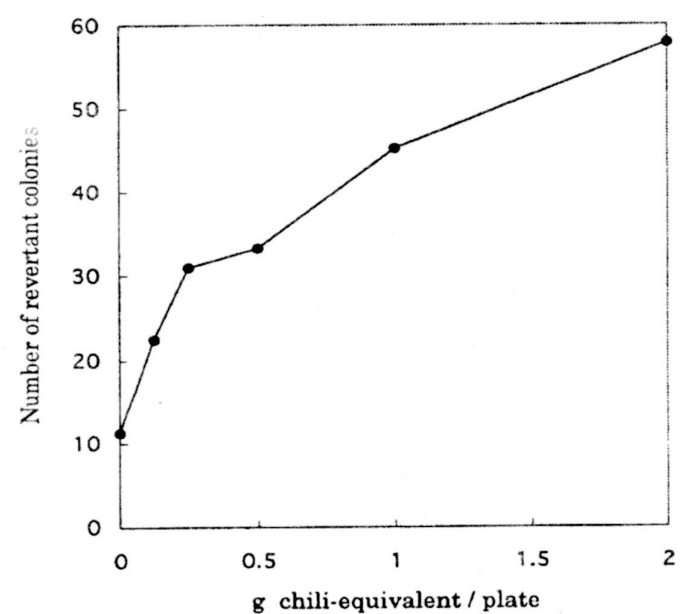

Fig. 2. Mutagenic activity of fraction 5. (The Ames assay was performed using Salmonella Typhimurium TA98 with metabolic activation).

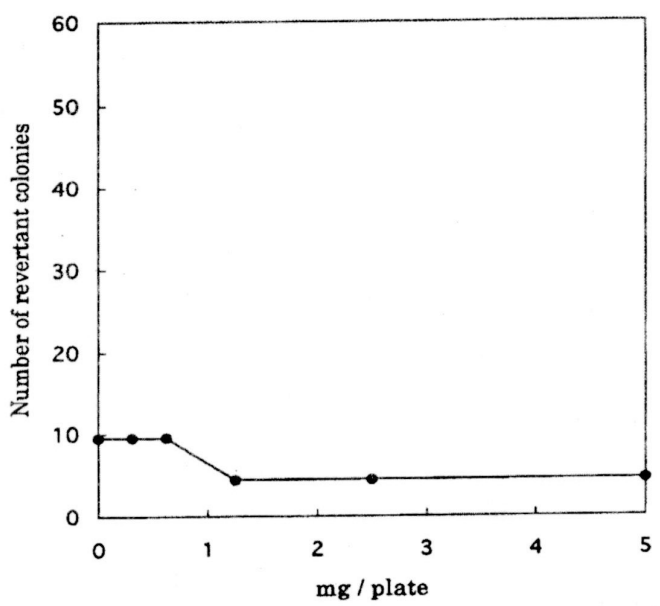

Fig. 3. Mutagenic activity of capsaicin (synthesized). 


\section{5. p53 Analysis of GBC}

Mutations in the p53 tumor suppressor gene are the most frequently observed genetic lesions in human cancers of the colon, lung, breast, esophagus, liver, and other organs. In the case of GBC, however, nothing was known until the report of Takagi et al. (1994). Consequently, Yokoyama et al. (1998) conducted an analysis of p53 alterations in GBC in high-incidence areas of Chile and Japan.

The percentages of tumors positive for gene mutations were $55.0 \%$ in Santiago and $50.0 \%$ in Niigata, with no statistically significant difference. The base-change spectrum of p53 was then examined. All 12 mutations in Santiago were transitions, with 4 arising at $\mathrm{CpG}$ sites (33.3\%). In Japan, there were 4 transversion types (30.8\%) in addition to 9 transitions. In summary, there may be regional differences in the factors causing mutation of the p53 tumor suppressor gene.
Based on these comparative studies of GBC between Chile and Japan, we recommended that new research projects be conducted to further our understanding of GBC. First of all, an analysis of genetic susceptibility with regard to the occurrence of GBC is needed. In a preliminary study, we found an elevated frequency of HLA-DR4 antigen in GBC cases in Japan (Yamamoto et al., 1990). A dendrogram of HLA-DR antigens placed the Japanese groups and American Indians in one cluster, with a genetic distance of only 0.3284 (Tsuji et al., 1986). Thus analysis of genetic susceptibility with regard to GBC is an important priority in order to pave the way to understanding neoplasia in the gallbladder more completely. Secondly, we must identify mutagens/carcinogens in gallbladder bile and chili peppers. Finally, it is also a priority to examination of other oncogenes or tumor suppressor genes is warranted in order to clarify the natural history of GBC.

\section{REFERENCES}

CHEN, W., ENDOH, K., YAMAMOTO, M., KATO, T. 1990 International comparison of the mortalities of biliary tract cancer. $\mathbf{J}$. Aichi. Med. Univ. Assoc. 18: 187-92.

ENDOH, K., NAKADAIRA, H., MANO, H., ADACHI, Y., 1993 KODAMA, K., KATAGIRI, M., et al. Epidemiology of biliary tract cancer in Japan: Descriptive studies. Acta Med. Biol. 41: 113-25.

ENDOH, K., NAKADAIRA, H., YAMAZAKI, O., 1997 YAMAMOTO, M., TAJIMA, K., SERRA, I., et al. Risk factors for gallbladder cancer in Chilean females Jpn. J. Pub. Health 44:113-22.

KATO, K., AKAI, S., TOMINAGA, S., KATO, 1. A case-con1990 trol study of biliary tract cancer in Niigata prefecture. Jpn. J. Clin. Oncol. 20: 67-71

KODAMA, K., NAKADA IRA, H., ENDOH, K., YAMAMOTO, 1998 M. Geographic clustering patterns in mortality from biliary tract cancer in Japan. Jpn. J. Cancer Res. 89: 6-11.

MANO, H., ROA, I. E., ARAYA, J.C., OHTA, T., YOSHIDA, 1996 K., ARAKI, K., et al. Comparison of mutagenic activity of Chile between Chilean and Japanese female patients having cholelithiasis. Mutation Res. 371:73-7.

SERRA, I., BAEZ, S. ENDOH, K., YAMAMOTO, M., 1996 CALVO, A. DECINTI, E. et al. Cáncer vesicular: estudio de casos y controles en Chile. Rev. Chilena de Cirugía 48: 139-47.

TAKAGI, S., NAITO, E., YAMANOUCHI, H., OHTSUKA, H., 1994 KOMINAMI, R., YAMAMOTO, M. Mutation of the p53 gene in gallbladder cancer. Tohoku J. Exp. Med. 172: 283-9.

TSUJI, K., SAITO, K., NOSE, Y, INOKO, H., NAKATSUJI, 1986 T., ANDO, A., es al. Differences between ethnic groups. In: Solheim BG, Moller E, Ferrone S, editors. HLA class II antigens: A comprehensive review of structure and function. Berlin; Springer-Verlag, 154-68.

YAMAMOTO, M. , HAGA, M., TAKAGI, S., ENDOH, K., ITO, 1990 S., YOSHIDA, K., et al. HLA ansigens in cancer of the gallbladder. Tohoku. J. Exp. Med. 161: 69-71.

YAMAMOTO, M ENDOH, K., NAKADAIRA, H., MANO, 1993 H., KATAGIRI, M., YAMAZAKI, $\mathrm{O}$, et al. Epidemiology of biliary tract cancer in Japan: Analytical studies. Acta Med. Biol. 41: 127-38.

YOKOYAMA, N., HITOMI, J., WATANABE, H., AJIOKA, Y., 1998 PRUYAS, M., SERRA, I., SHIRAI, Y., HATAKEYAMA, K. Mutations of p53 in gallbladder carcinomas in highincidence areas of Japan and Chile. Cancer Epidemiol. Biomark Prey. 7: 297-301. 
